\section{Peach Blossom String Thinner Performance Improved with Selective Pruning}

\author{
James R. Schupp \\ The Pennsylvania State University Fruit Research and Extension Center, 290 \\ University Drive, Biglerville, PA 17307
}

T. Auxt Baugher ${ }^{1}$

The Pennsylvania State University Cooperative Extension in Adams County, 670 Old Harrisburg Road, Gettysburg, PA 17325

Additional index words. Prunus persica, mechanical thinning, cropload, peach fruit quality, fruit set, labor efficiency, stone fruit

\begin{abstract}
Hand-thinning of fruit is among the most labor-intensive orchard practices and consequently contributes significantly to peach (Prunus persica) production costs. Prior research conducted by the authors on string blossom thinners for managing peach tree cropload demonstrated that this new technology reduces labor requirement and also improves fruit size. Studies were conducted over two seasons in peach orchards trained to perpendicular $\mathrm{V}$ or open-center systems to evaluate possible pruning strategies to improve tree canopy access by string thinners. The objectives were to demonstrate if modifications in fruiting shoot orientation, pruning detail, and/or scaffold accessibility improved flower removal, reduced follow-up hand-thinning requirement, and/or increased fruit size. Blossom removal was improved by either detailed pruning or partial pruning (elimination of all shoots on the side of a limb inaccessible by the thinner spindle) in both training systems. Flower density and fruit set measurements revealed greater differences among pruning treatments compared with hand-thinned control treatments with both fruiting shoot orientation pruning modifications and detail pruning resulting in improved thinning. Thinning efficacy was unaffected by scaffold angle but increased as canopy accessibility ranking increased. Follow-up hand-thinning time was reduced by all treatment, system/ cultivar, and year combinations except standard pruning in an open center-trained 2009 trial. Detail pruning consistently improved fruit size compared with hand-thinned control and other pruning treatments in both perpendicular $\mathrm{V}$ - and open center-trained orchard plots. The best treatments resulted in a thinning savings of $\$ 120 /$ ha to $\$ 282 / \mathrm{ha}$ in perpendicular $V$ plantings and \$26/ha to \$46/ha in open-center plantings. Realized economic savings beyond hand-thinning alone ranged from $\$ 473 / \mathrm{ha}$ to $\$ 2875 / \mathrm{ha}$ in perpendicular $\mathrm{V}$ trials and $\$ 28 /$ ha to $\$ 293 /$ ha in open-center trials.
\end{abstract}

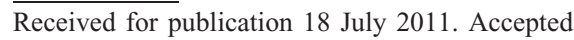
for publication 8 Sept. 2011.

This research was supported by the USDA Specialty Crop Research Initiative, the State Horticultural Association of Pennsylvania Extension Committee, the Pennsylvania Peach and Nectarine Board, the Washington Tree Fruit Research Commission, the Penn State College of Agriculture Seed Grant Program, the Pennsylvania Department of Community and Economic Development First Industries Program, and the Adams County Economic Development Corporation. We acknowledge the valuable contributions of $\mathrm{E}$. Winzeler, K. Ellis, K. Lesser Clowney, K. Reichard, J. Remcheck, C. Musselman, A. Leslie, J. Koan, R. Rohrbaugh, R. Hilton, A. Jarvinen, M. Reid, C. Anders, E. Moore, C. Kuntz, C. Witt, M. Tindall, M. Schupp, C. Sollenberger, M. Price, A. Betz, S. Betz, D. Kilmer, J. Cline, S. Aguilar, J. Lott, D. Kuhn, R. Lamb, S. Kuhn, D. Mickey, J. Mickey, D. Wenk, B. Wenk, J. Wenk, E. Rankin, A. Dias, C. Baugher, D. Lott, C. McCleaf, M. Rice, D. Slaybaugh, and B. Knouse.

The mention of a trademark, proprietary product, or vendor does not constitute a guarantee or warranty of the product and does not imply its approval to the exclusion of other products or vendors that also may be suitable.

${ }^{1}$ To whom reprint requests should be addressed; e-mail tab36@psu.edu.
Crop thinning is required in tree fruit production to ensure optimum fruit size and quality. The conventional method of cropload management in peach orchards is to remove excess fruit by hand after danger of frost is over, which is generally 35 to $40 \mathrm{~d}$ after full bloom (DAFB). This is labor-intensive with time for hand-thinning ranging from $62 \mathrm{~h} \cdot \mathrm{ha}^{-1}$ to over $247 \mathrm{~h} \cdot \mathrm{ha}^{-1}$ (Glozer and Hasey, 2006; Krawczyk, 2010). Plant growth regulators are available for thinning pome fruit; however, chemical thinning options for stone fruit are limited and unpredictable (Byers, 1999; Fallahi et al., 2006; Klein and Cohen, 2000; Miller and Tworkoski, 2010; Osborne et al., 2005; Stover and Greene, 2005; Wilkins et al., 2004).

Various peach mechanical thinning devices have been tested over the years, including trunk shakers (Berlage and Langmo, 1982; Powell et al., 1975), low-frequency electrodynamic limb shakers (Diezma and Rosa, 2005; Glozer and Hasey, 2006; Rosa et al., 2008), high-pressure water streams (Byers, 1990), rotating rope curtains (Baugher et al., 1991), and vibrating canopy shakers (Glenn et al., 1994; Miller et al., 2011). As growers have modified training systems for automation by maintaining narrow canopy widths, mechanical thinning options have become more attainable (Miller et al., 2011; Schupp et al., 2008).

Two types of string blossom thinners have in recent years been successfully tested and commercialized in European apple orchards trained to narrow canopies (Bertschinger et al., 1998; Damerow and Blanke, 2009; Damerow et al., 2007). Research with this new string thinner technology for managing peach cropload began in U.S. orchards in 2007 (Schupp et al., 2008). Studies on narrow canopies trained to perpendicular $\mathrm{V}$ or quadrilateral $\mathrm{V}$ systems demonstrated that mechanical thinning reliably reduces cropload, reduces labor requirement, and increases fruit size beyond that achieved with conventional hand-thinning of green fruit at 30 to 40 DAFB. A 2008 prototype designed to operate in a horizontal position had similar effects on peach trees trained to an opencenter system (Baugher et al., 2009). The next year, a string thinner was manufactured that operated in either a vertical or horizontal position, and trials conducted in four peachproducing regions on both narrow vertical and open-center canopies demonstrated reductions in follow-up hand-thinning requirement and increases in yield and fruit size (Baugher et al., 2010a). Pennsylvania trials conducted with the hybrid thinner on both perpendicular V- and open center-trained trees at various bloom stages showed that the window for thinning peach and nectarine trees ranges from the pink to the petal fall stage of bloom development (Baugher et al., 2010b).

Studies were conducted in Pennsylvania peach orchards in 2008 and 2009 to evaluate possible pruning strategies to improve peach tree canopy access by string thinners. Research on scaffold angle and accessibility was conducted in 2009. The objectives were to demonstrate if modifications in fruiting shoot orientation, pruning detail, and/or scaffold accessibility improved string thinner performance based on 1) increased flower removal; 2) reduced follow-up hand-thinning requirement; and/or 3 ) increased fruit size.

\section{Materials and Methods}

Mechanical string thinner description. A vertical string thinner originally designed to thin blossoms from pyramid-shaped apple trees (Darwin 300; Fruit-Tec, Deggenhausertal, Germany; Fig. 1A) was evaluated on perpendicular V-trained peach trees. The thinner has a 3.0-m-long spindle that is oriented in a vertical position and tilts $30^{\circ}$ in either direction from center. A hybrid string thinner (PT 250; FruitTec; Fig. 1B) was used to thin open centertrained peach trees. This thinner, designed to thin peach trees of variable forms (Baugher et al., 2010a), has a $2.5-\mathrm{m}$-long spindle that tilts from $120^{\circ}$ to $270^{\circ}$ from vertical and can thus be oriented in either a vertical or a horizontal position. On both string thinner models, the spindle is powered by a hydraulic motor 
and speed is adjusted by a proportional flow control valve. The intensity of thinning is adjustable by changing the spindle rotation speed, the tractor speed, or the string arrangement. Two columns of strings were used, arranged with alternating gaps, for a total of 90 strings. The string thinner was fitted with plastic strings and operated at $180 \mathrm{rpm}$ and $4.0 \mathrm{~km} \cdot \mathrm{h}^{-1}$ in 2008 and fitted with molded strings and operated at $150 \mathrm{rpm}$ and $4.0 \mathrm{~km} \cdot \mathrm{h}^{-1}$ in 2009. Length of both string types was $61.5 \mathrm{~cm}$. The manufacturer changed the string technology in 2009 , and it was important to test the strings that commercial growers would be using as they adopted the non-selective thinning strategy. Extensive pre-tests were conducted in 2009 to ensure that the string arrangement, rpm, and tractor speed used with both string types produced similar levels of thinning (data not presented).

Pruning modification trials conducted in commercial orchards. Mechanical thinning trials were conducted over two seasons in commercial Pennsylvania plantings of mature perpendicular V-trained 'Sugar Giant' and 'John Boy' peach trees and during one season in open center-trained 'Loring' and 'PF20-007'. Tree spacing was $6.1 \times 1.8 \mathrm{~m}$ and $6.1 \times 3.7 \mathrm{~m}$, respectively. Pruning treatments in perpendicular V blocks included 1) standard (fruiting shoots left on all sides of each of two scaffolds); 2) fan (fruiting shoots selected in two directions parallel to the row); and 3) partial fan (fruiting shoots left parallel to the row or extending toward row middles but not toward the center of the tree) (Fig. 2A). Two additional pruning treatments - 4) standard pruning with detailed cuts to eliminate short (less than $15 \mathrm{~cm}$ ) or excessively long (greater than $45 \mathrm{~cm}$ ) shoots; and 5) standard pruning post-bloom (after mechanically thinning) - were evaluated in 2009. Pruning treatments in open center blocks included 1) standard (fruiting shoots left on all sides of each of four scaffolds); 2) partial (secondary branches minimized and fruiting shoots selected on the sides and tops of each scaffold but not the undersides); and 3) detail (standard pruning with detailed cuts to eliminate short or excessively long shoots) (Fig. 2B). Uniform numbers of fruiting shoots were left in each treatment within a training system-60 in perpendicular V-trained trees and 125 in open center-trained trees. Based on earlier studies that determined optimum bloom stage for thinning, trees were mechanically thinned when $20 \%$ to $80 \%$ of the blossoms were open (Baugher et al., 2010b). Mechanically thinned pruning treatments were compared with green fruit hand-thinned (35 DAFB) control treatments on trees with standard pruning.

The experimental design in each trial was a randomized complete block with six blocks and six-tree plots. Data were collected from two center trees in each plot. Flower density and cropload were determined on two pretagged scaffolds on each of the test trees. Initial blossom density ranged from 10 to 16 flowers $/ \mathrm{cm}^{2}$ limb cross-sectional area in
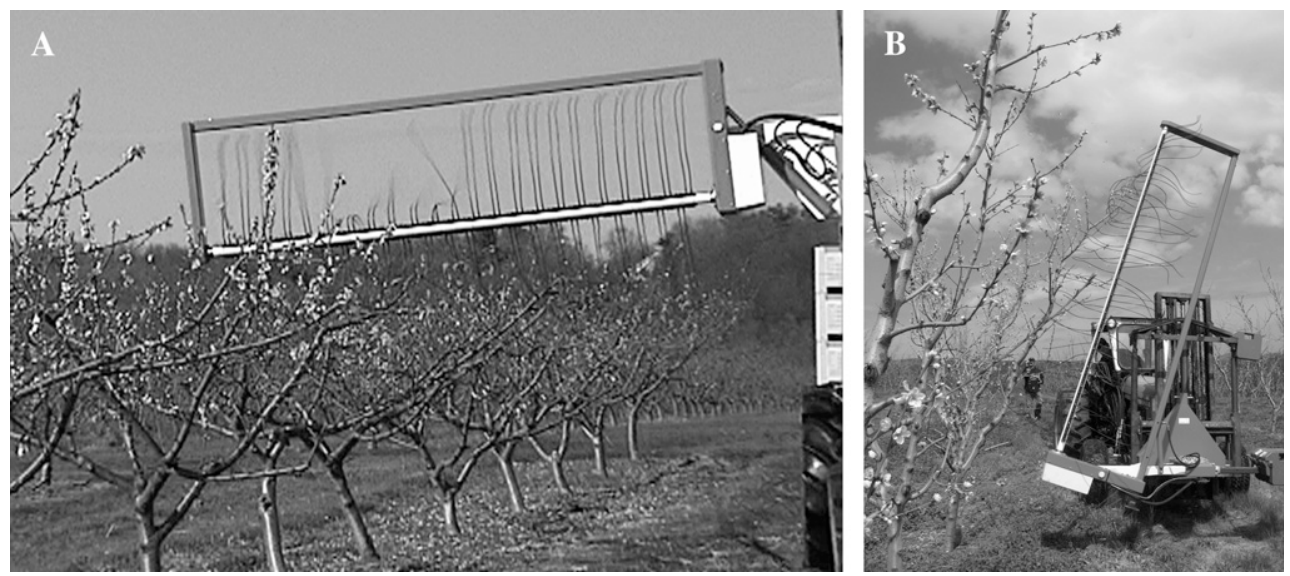

Fig. 1. Vertical string blossom thinner evaluated for thinning peach trees trained to perpendicular V (A) and hybrid string thinner prototype tested on peach trees trained to an open center system (B; photograph by M. Wherley). The string thinner spindles were fitted with two columns of strings arranged with alternating gaps. Plastic strings (shown in A) made for pre-2009 versions of the string thinner were used in 2008, and molded strings (B) developed for 2009 and 2010 string thinner models were used in 2009. Extensive pre-tests were conducted to ensure that the string arrangement, rpm, and tractor speed used with both string types produced similar levels of thinning.

A. Pruning Treatments in Perpendicular V System

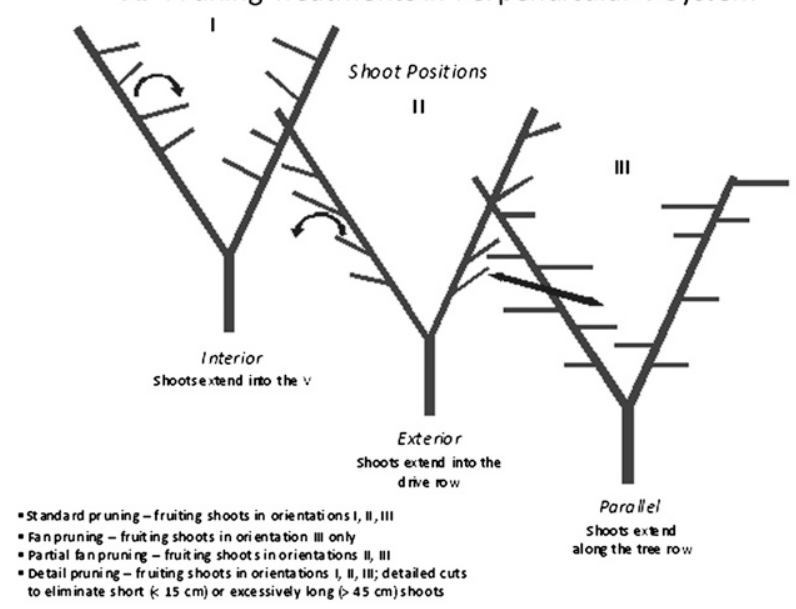

B. Pruning Treatments in Open Center System

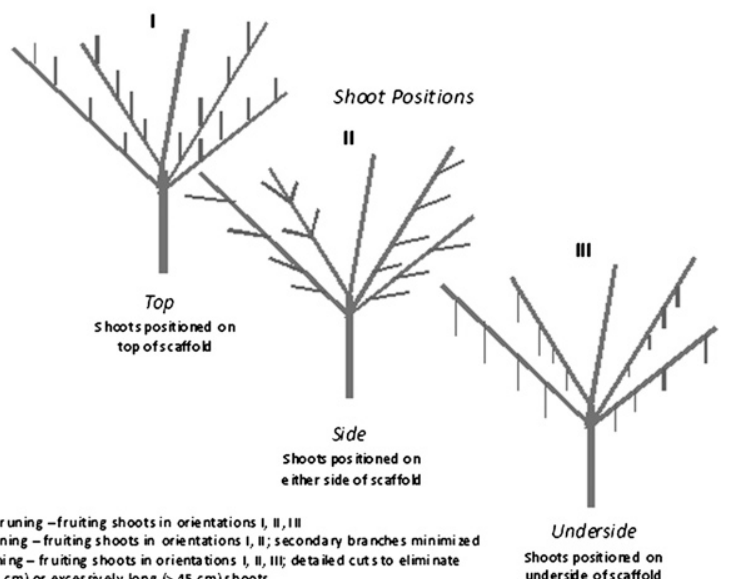

Fig. 2. Line drawings illustrating pruning treatments in perpendicular-V trained 'Sugar Giant' and 'John Boy' peach trees (A) and in open center-trained 'Loring' and 'PF20-007' peach trees (B). 
perpendicular $\mathrm{V}$-trained trees and 23 to 26 flowers $/ \mathrm{cm}^{2}$ limb cross-sectional area in open center-trained trees. Blossom removal with mechanical thinners was evaluated by counting all blossoms in the upper and lower canopy regions of the tagged scaffolds immediately before and after thinning. The total number of blossoms per scaffold also was compared. Reduction in flower/fruit density was evaluated the day of thinning and again after physiological drop (35 to 40 DAFB) by calculating number of blossoms or fruit per limb crosssectional area in the upper and lower canopies and scaffold. All trees were uniformly hand-thinned by growers to commercial levels, during which follow-up hand-thinning time was recorded. At harvest, a sample of 40 firm-ripe fruit collected from the two center trees in each plot was evaluated for mean fruit diameter and fruit size distribution. Yields were calculated from fruit per scaffold counts and percent size distribution. All data were subjected to an analysis of variance and treatments were separated using Fisher's protected least significant difference test.

Economic partial budget analyses (described by Harper et al., 2002) were performed to evaluate the potential impact of each thinning treatment on fruit returns. Mechanical thinning costs, based on a 15 -year life of equipment and $8 \%$ interest rate, averaged $\$ 37 /$ ha for the string thinner, including tractor cost $(\$ 12.00 / \mathrm{h})$ and labor $(\$ 12.00 / \mathrm{h})$. Realized economic savings were calculated from follow-up hand-thinning time, fruit size distribution, and average yield. Follow-up handthinning costs were based on a labor rate of $\$ 8.50 / \mathrm{h}$ in 2008 and $\$ 8.75 / \mathrm{h}$ in 2009 . Commercial prices for the various size categories for each cultivar and year were obtained from the USDA Agricultural Marketing Service Report, Appalachian Region (USDA, 2009).

Commercial-scale trial to evaluate thinning efficacy with variable scaffold angles and accessibility rankings. Regression analyses were conducted to access string thinner efficacy on 'Allstar' and 'Saturn' perpendicular V-trained peach trees with variable scaffold angles and accessibility rankings. Plot size averaged 245 trees. Treatments were applied with the vertical string thinner fitted with molded strings and operated at $150 \mathrm{rpm}$ and $4.0 \mathrm{~km} \cdot \mathrm{h}^{-1}$. Estimated percent blossom removal for each scaffold was compared with scaffold angle and also a canopy accessibility score of 1 (poor accessibility) to 5 (excellent accessibility). Crooked scaffolds or scaffolds that were not perpendicular to the row were given the lower rankings, and straight, unobscured scaffolds that were oriented close to $90^{\circ}$ from the row direction were given the highest accessibility ratings.

\section{Results and Discussion}

Blossom removal, flower density, fruit set, and follow-up hand-thinning comparisons. Blossom removal was improved by either detailed pruning or partial pruning in both training systems (Fig. 3). The detailed pruning and partial pruning treatments compared
John Boy, 2008

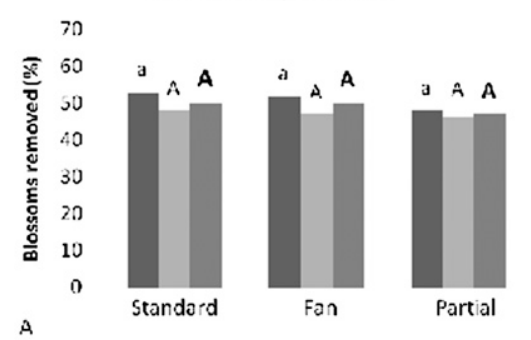

John Boy, 2009

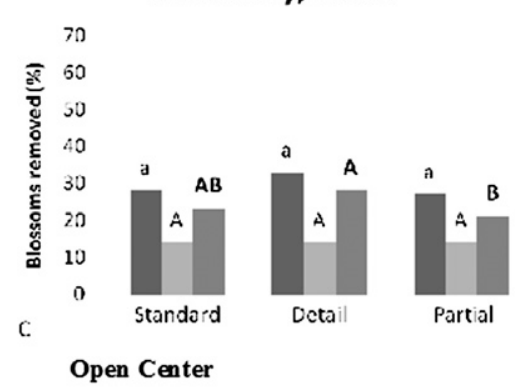

Loring, 2009

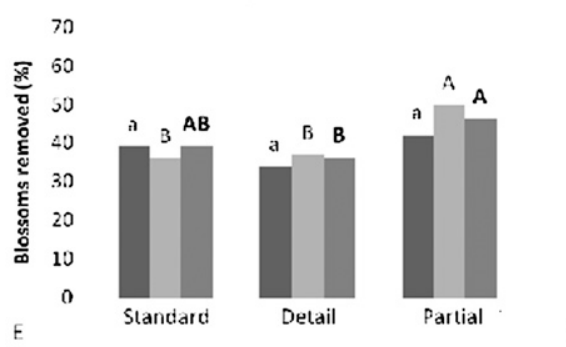

White Lady, 2008

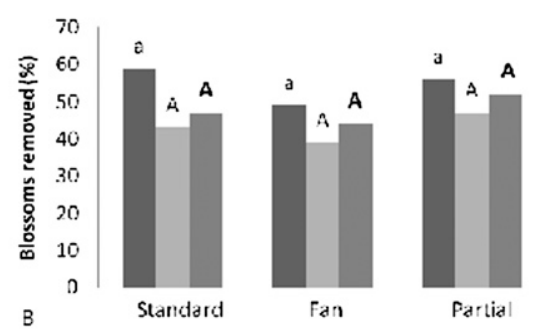

White Lady, 2009

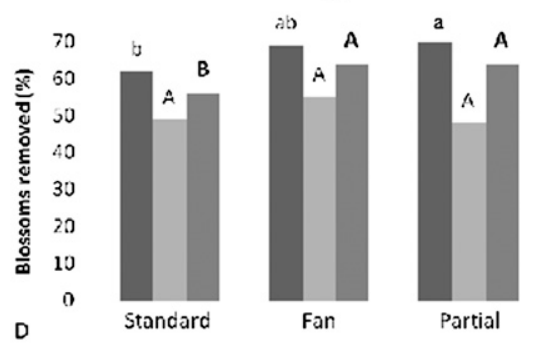

\section{-Upper canopy ㄴ. Lower canopy = Scaffold}

Fig. 3. Peach blossom removal with a string thinner in response to various pruning treatments. The string thinner was fitted with plastic strings and operated at $180 \mathrm{rpm}$ and $4.0 \mathrm{~km} \cdot \mathrm{h}^{-1}$ in 2008 and fitted with molded strings and operated at $150 \mathrm{rpm}$ and $4.0 \mathrm{~km} \cdot \mathrm{h}^{-1}$ in 2009 . Mean separation within cultivars, years, and canopy position by Fisher's protected least significant difference at $P \leq 0.05$ (lower case letters for upper canopy, upper case letters for lower canopy, bold letters for scaffold).

with standard pruning treatments resulted in a greater number of blossoms thinned in the 2009 'John Boy' and 'PF20-007' trials and the 2009 'White Lady' trial, respectively. Blossom removal was similar across pruning treatments in 2008 with the exception that removal in the fan treatment was no different from the control. Pruning in the detail and partial pruned plots was more selective than pruning in the standard pruned plots, which resulted in improved access for mechanical thinning.

Flower density and fruit set measurements revealed greater differences among pruning treatments compared with hand-thinned control treatments, especially in upper canopy regions of the trees (Table 1 ). In perpendicular V-trained trees, blossom density in upper canopy regions was reduced in the 2009 'John Boy' trial by delayed (post-bloom) pruning or detail pruning and in both years of 'White Lady' trials by fan or partial pruning com- pared with other pruning treatments. Whole scaffold blossom density was reduced in the 2009 'John Boy' study by detail pruning and in the 2009 'White Lady' study by fan pruning (although the difference was insignificant compared with partial pruning). Fruit set (upper canopy, lower canopy, and scaffold) in the same trials was reduced in 'John Boy' by detail pruning and in 'White Lady' (upper scaffold, 2008 only) by partial pruning. Fruit set in post-bloom-pruned trees was similar to hand-thinned control trees, and the fruitlets were small compared with the other treatments. In open center-trained trees, blossom density and cropload were reduced in all canopy regions of 'Loring' by partial compared with standard pruning, but the numbers of flowers or fruit were similar to detail pruning. Blossom density and cropload (lower canopy and total scaffold) were reduced by detail pruning compared with standard pruning, yet the numbers of flowers were similar 
Table 1. Peach blossom thinning and fruit set response to vertical string thinner treatments applied to varying pruning modifications in 2008 and 2009.

\begin{tabular}{|c|c|c|c|c|c|c|}
\hline \multirow[b]{2}{*}{ Thinning treatment ${ }^{\mathrm{x}}$} & \multicolumn{3}{|c|}{$\begin{array}{c}\text { Flower density after thinning }{ }^{z} \\
\text { (flowers/cm² limb-cross-sectional area) }\end{array}$} & \multicolumn{3}{|c|}{$\begin{array}{c}\text { Cropload (density) } 35 \text { DAFB }^{\mathrm{y}} \\
\text { (fruit } / \mathrm{cm}^{2} \text { limb-cross-sectional area) }\end{array}$} \\
\hline & Upper canopy & Lower canopy & Scaffold & Upper canopy & Lower canopy & Scaffold \\
\hline & \multicolumn{6}{|c|}{$\begin{array}{c}\text { Perpendicular V } \\
\text { John Boy } \\
2008\end{array}$} \\
\hline Fan pruning, $20 \% \mathrm{FB}^{\mathrm{w}}$ & $7.3 \mathrm{~b}^{\mathrm{v}}$ & $3.3 \mathrm{~b}$ & $7.2 \mathrm{~b}$ & $3.5 \mathrm{~b}$ & $1.9 \mathrm{~b}$ & $3.8 \mathrm{~b}$ \\
\hline Partial pruning, $20 \% \mathrm{FB}$ & $6.9 \mathrm{~b}$ & $3.2 \mathrm{~b}$ & $7.0 \mathrm{~b}$ & $3.5 \mathrm{~b}$ & $1.8 \mathrm{~b}$ & $3.8 \mathrm{~b}$ \\
\hline Standard pruning, $20 \%$ FB & $8.4 \mathrm{~b}$ & $3.3 \mathrm{~b}$ & $7.4 \mathrm{~b}$ & $3.9 \mathrm{~b}$ & $1.8 \mathrm{~b}$ & $3.9 \mathrm{~b}$ \\
\hline \multirow[t]{2}{*}{ Hand-thinned control, 35 DAFB } & $19.5 \mathrm{a}$ & $6.2 \mathrm{a}$ & $15.8 \mathrm{a}$ & $7.8 \mathrm{a}$ & $2.8 \mathrm{a}$ & $6.7 \mathrm{a}$ \\
\hline & \multicolumn{6}{|c|}{$\begin{array}{l}\text { John Boy } \\
2009\end{array}$} \\
\hline Delayed pruning, $80 \% \mathrm{FB}$ & $9.2 \mathrm{c}$ & $5.7 \mathrm{a}$ & $10.9 \mathrm{~b}$ & $10.0 \mathrm{ab}$ & $3.1 \mathrm{a}$ & $8.7 \mathrm{a}$ \\
\hline Detail pruning, $80 \% \mathrm{FB}$ & $9.2 \mathrm{c}$ & $2.5 \mathrm{~b}$ & $7.4 \mathrm{c}$ & $5.6 \mathrm{c}$ & $1.7 \mathrm{~b}$ & $4.6 \mathrm{~b}$ \\
\hline Standard pruning, $80 \% \mathrm{FB}$ & $14.3 \mathrm{~b}$ & $5.2 \mathrm{a}$ & $12.9 \mathrm{~b}$ & $7.4 \mathrm{bc}$ & $3.6 \mathrm{a}$ & $7.6 \mathrm{a}$ \\
\hline \multirow[t]{2}{*}{ Hand-thinned control, 35 DAFB } & $19.4 \mathrm{a}$ & $5.7 \mathrm{a}$ & $15.8 \mathrm{a}$ & $10.3 \mathrm{a}$ & $3.5 \mathrm{a}$ & $8.9 \mathrm{a}$ \\
\hline & \multicolumn{6}{|c|}{$\begin{array}{c}\text { White Lady } \\
2008\end{array}$} \\
\hline Fan pruning, $20 \% \mathrm{FB}$ & $7.9 \mathrm{c}$ & $3.2 \mathrm{~b}$ & $5.8 \mathrm{~b}$ & $3.9 \mathrm{bc}$ & $1.3 \mathrm{~b}$ & $2.6 \mathrm{~b}$ \\
\hline Partial pruning, $20 \% \mathrm{FB}$ & $8.0 \mathrm{c}$ & $3.1 \mathrm{~b}$ & $5.7 \mathrm{~b}$ & $3.2 \mathrm{c}$ & $1.4 \mathrm{~b}$ & $2.5 \mathrm{~b}$ \\
\hline Standard pruning, $20 \% \mathrm{FB}$ & $12.1 \mathrm{~b}$ & $3.6 \mathrm{~b}$ & $7.3 \mathrm{~b}$ & $4.7 \mathrm{~b}$ & $1.2 \mathrm{~b}$ & $2.5 \mathrm{~b}$ \\
\hline \multirow[t]{2}{*}{ Hand-thinned control, 35 DAFB } & $20.4 \mathrm{a}$ & $5.9 \mathrm{a}$ & $13.0 \mathrm{a}$ & $7.6 \mathrm{a}$ & $2.2 \mathrm{a}$ & $4.9 \mathrm{a}$ \\
\hline & \multicolumn{6}{|c|}{$\begin{array}{l}\text { White Lady } \\
2009\end{array}$} \\
\hline Fan pruning, $60 \% \mathrm{FB}$ & $3.3 \mathrm{c}$ & $1.3 \mathrm{~b}$ & $2.7 \mathrm{c}$ & $1.0 \mathrm{~b}$ & $0.5 \mathrm{~b}$ & $0.9 \mathrm{~b}$ \\
\hline Partial pruning, $60 \% \mathrm{FB}$ & $2.8 \mathrm{c}$ & $1.8 \mathrm{~b}$ & $3.1 \mathrm{bc}$ & $0.9 \mathrm{~b}$ & $0.5 \mathrm{~b}$ & $0.9 \mathrm{~b}$ \\
\hline Standard pruning, $60 \% \mathrm{FB}$ & $6.9 \mathrm{~b}$ & $2.2 \mathrm{~b}$ & $4.9 \mathrm{~b}$ & $1.8 \mathrm{~b}$ & $0.7 \mathrm{~b}$ & $1.4 \mathrm{~b}$ \\
\hline \multirow[t]{2}{*}{ Hand-thinned control, 35 DAFB } & $16.9 \mathrm{a}$ & $3.6 \mathrm{a}$ & $10.7 \mathrm{a}$ & $5.6 \mathrm{a}$ & $1.1 \mathrm{a}$ & $3.5 \mathrm{a}$ \\
\hline & \multicolumn{6}{|c|}{ Open center } \\
\hline Detail pruning, $60 \% \mathrm{FB}$ & $15.7 \mathrm{bc}$ & $5.8 \mathrm{bc}$ & $13.0 \mathrm{~b}$ & $10.8 \mathrm{bc}$ & $3.9 \mathrm{bc}$ & $9.0 \mathrm{~b}$ \\
\hline Partial pruning, $60 \% \mathrm{FB}$ & $10.8 \mathrm{c}$ & $3.4 \mathrm{c}$ & $8.1 \mathrm{c}$ & $6.9 \mathrm{c}$ & $1.9 \mathrm{c}$ & $4.7 \mathrm{c}$ \\
\hline Standard pruning, $60 \% \mathrm{FB}$ & $17.5 \mathrm{ab}$ & $7.4 \mathrm{~b}$ & $16.7 \mathrm{~b}$ & $11.0 \mathrm{bc}$ & $5.3 \mathrm{~b}$ & $11.3 \mathrm{~b}$ \\
\hline \multirow[t]{2}{*}{ Hand-thinned control, 35 DAFB } & $22.7 \mathrm{a}$ & $11.8 \mathrm{a}$ & $23.4 \mathrm{a}$ & $13.7 \mathrm{a}$ & $7.6 \mathrm{a}$ & $14.5 \mathrm{a}$ \\
\hline & \multicolumn{6}{|c|}{$\begin{array}{l}\text { PF20-007 } \\
2009\end{array}$} \\
\hline Detail pruning, $60 \% \mathrm{FB}$ & $11.8 \mathrm{c}$ & $4.4 \mathrm{c}$ & $9.2 \mathrm{c}$ & $3.5 \mathrm{c}$ & $1.3 \mathrm{~b}$ & $2.7 \mathrm{c}$ \\
\hline Partial pruning, $60 \% \mathrm{FB}$ & $14.6 \mathrm{bc}$ & $6.2 \mathrm{bc}$ & $14.5 \mathrm{bc}$ & $5.3 \mathrm{ab}$ & $2.6 \mathrm{a}$ & $5.5 \mathrm{~b}$ \\
\hline Standard pruning, $60 \% \mathrm{FB}$ & $10.5 \mathrm{c}$ & $8.6 \mathrm{~b}$ & $15.7 \mathrm{~b}$ & $3.5 \mathrm{~b}$ & $5.6 \mathrm{a}$ & $4.9 \mathrm{~b}$ \\
\hline Hand-thinned control, 35 DAFB & $20.4 \mathrm{a}$ & $11.1 \mathrm{a}$ & $25.5 \mathrm{a}$ & $7.0 \mathrm{a}$ & $3.5 \mathrm{a}$ & $8.4 \mathrm{a}$ \\
\hline
\end{tabular}

z1 flower or fruit $/ \mathrm{cm}^{2}=6.4516$ flowers or fruit $/$ inch $^{2}$.

${ }^{y} \mathrm{DAFB}=$ days after full bloom; before follow-up hand-thinning.

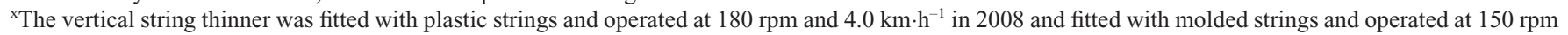
and $4.0 \mathrm{~km} \cdot \mathrm{h}^{-1}$ in $2009.1 .0 \mathrm{~km}^{-1}=0.6214 \mathrm{mph}$.

${ }^{\mathrm{w}} \mathrm{FB}=$ full bloom

'Mean separation within columns, cultivars, and years by Fisher's protected least significant difference at $P \leq 0.05$.

to partial pruning. Thinning improvements related to shoot position were consistent with those reported by Schupp et al. (2008) in a study in which flower removal on shoots growing toward the row, toward the center of the tree, and parallel to the row was compared. Thinning improvements with detailed pruning resulted from prior removal of long shoots that tend to get bent by the strings and short shoots that are often missed. These shoots produce poorer quality fruit based on research conducted by Marini (2009); therefore, removal by pruning further impacts fruit size.

Follow-up hand-thinning time was reduced by all treatment, system/cultivar, and year combinations except the standard pruning in the open center-trained 'Loring' in the 2009 trial (Table 2). Detail pruning was the only treatment that reduced hand-thinning time compared with other pruning strategies. Follow-up hand-thinning on mechanically thinned, detail-pruned trees compared with green fruit thinned, standard-pruned trees was reduced by $46 \%$ in perpendicular V-trained 'John Boy' (2009) and by $22 \%$ and $47 \%$, respectively, in open center-trained 'Loring' and 'PF20-007' (2009). Mechanically thinned 'White Lady' (2009) trees did not require follow-up thinning because they had been bloom-thinned too heavily. In mechanically thinned 'John Boy', 'White Lady' (2008), 'Loring', and 'PF20-007', follow-up handthinning time ranged from 42.1 to $66.4 \mathrm{~h} \cdot \mathrm{ha}^{-1}$, 19.0 to $21.7 \mathrm{~h} \cdot \mathrm{ha}^{-1}, 24.0$ to $27.8 \mathrm{~h} \cdot \mathrm{ha}^{-1}$, and 10.3 to $14.8 \mathrm{~h} \cdot \mathrm{ha}^{-1}$, respectively. Follow-up thinning time for hand-thinned control trees was $78.3,36.6,30.7$, and $19.3 \mathrm{~h} \cdot \mathrm{ha}^{-1}$ in the same trials. The follow-up hand-thinning data, along with bloom and fruit set data, confirm previous reports indicating the importance of careful assessment of bloom density to determine best use of mechanical thinning tech- nology (Baugher et al., 2009, 2010a; Schupp et al., 2008).

Fruit size, yield, and labor comparisons. Detail pruning consistently improved fruit size compared with hand-thinned control and other pruning treatments in both open centerand perpendicular V-trained orchard plots (Table 3). Partial pruning was equal to detail pruning in just one trial-the 'PF20-007' plot. Detail pruning also increased the percentage of fruit in higher market value size categories (fruit $7.0 \mathrm{~cm}$ or greater and/or 7.6 $\mathrm{cm}$ or greater) in all trials except 'Loring'. Detail pruning was not included as a treatment in the 2008 'John Boy' trial, and fan pruning was the only treatment that resulted in improved size distribution compared with the hand-thinned control. Previous research showed no difference in effects on fruit size in the upper versus lower canopy (Schupp et al., 2008). Although total calculated yield 
Table 2. Follow-up hand-thinning time required with vertical string thinner treatments applied to varying pruning modifications in 2008 and 2009.

\begin{tabular}{lc}
\hline & Hand-thinning \\
& at 35 to 40 \\
Thinning treatment $^{\mathrm{y}}$ & $\mathrm{DAFB}^{\mathrm{z}}\left(\mathrm{h} \cdot \mathrm{ha}^{-1}\right)^{\mathrm{x}}$ \\
\hline & Perpendicular V \\
& John Boy \\
& $2009^{w}$ \\
Delayed pruning, 80\% FB & $66.2 \mathrm{~b}^{\mathrm{v}}$ \\
Detail pruning, 80\% FB & $42.1 \mathrm{c}$ \\
Standard pruning, 80\% FB & $66.4 \mathrm{~b}$ \\
Hand-thinned control, 35 & $78.3 \mathrm{a}$
\end{tabular}

$$
\text { DAFB }
$$

Fan pruning, 20\% FB

Partial pruning, $20 \% \mathrm{FB}$

Standard pruning, $20 \% \mathrm{FB}$

Hand-thinned control, 35

DAFB

Fan pruning, 60\% FB

Partial pruning, $60 \% \mathrm{FB}$

Standard pruning, $60 \% \mathrm{FB}$

Hand-thinned control, 35

DAFB

Detail pruning, $60 \% \mathrm{FB}$

Partial pruning, $60 \%$ FB

Standard pruning, $60 \% \mathrm{FB}$

Hand-thinned control, 35

DAFB

$\begin{array}{lc} & P F 20-007 \\ & 2009 \\ \text { Detail pruning, 60\% FB } & 10.3 \mathrm{c} \\ \text { Partial pruning, 60\% FB } & 14.3 \mathrm{~b} \\ \text { Standard pruning, 60\% FB } & 14.8 \mathrm{~b} \\ \text { Hand-thinned control, 35 } & 19.3 \mathrm{a} \\ \text { DAFB } & \end{array}$

$\frac{\mathrm{DAFB}}{{ }^{\mathrm{z}} \mathrm{DAFB}=\text { days after full bloom; FB }=\text { full bloom. }}$

${ }^{\mathrm{y}}$ The vertical string thinner was fitted with plastic strings and operated at $180 \mathrm{rpm}$ and $4.0 \mathrm{~km} \cdot \mathrm{h}^{-1}$ in 2008 and fitted with molded strings and operated at $150 \mathrm{rpm}$ and $4.0 \mathrm{~km} \cdot \mathrm{h}^{-1}$ in $2009.1 .0 \mathrm{~km} \cdot \mathrm{h}^{-1}=$ $0.6214 \mathrm{mph}$.

${ }^{\mathrm{x}} 1 \mathrm{~h} \cdot \mathrm{ha}^{-1}=0.4047 \mathrm{~h} /$ acre.

wNo data for 'John Boy' in 2008.

"Mean separation within cultivars and years by Fisher's protected least significant difference at $P \leq 0.05$.

of mechanically thinned trees was sometimes reduced compared with hand-thinned control trees, yield of high market value-sized fruit was sometimes increased (Table 3). This finding is similar to results of earlier research with either the hybrid or vertical string thinner (Baugher et al., 2010a; Schupp et al., 2008). A 2008 mechanical thinning trial in which detailed yield data were collected at each harvest date demonstrated that early harvest yield of mechanically blossom-thinned trees was greater than early yield of trees in hand-thinned control and non-thinned treatments and that thinning treatment did not affect total yield (Baugher et al., 2009).
Table 3. Peach fruit size, packout distribution, and high market value yield as affected by string thinner treatments applied to varying pruning modifications in 2008 and 2009.

\begin{tabular}{|c|c|c|c|c|c|}
\hline Thinning treatment & $\begin{array}{l}\text { Fruit diam } \\
\qquad(\mathrm{cm})^{\mathrm{z}}\end{array}$ & $\begin{array}{c}\text { Fruit } 7.0 \mathrm{~cm} \text { or } \\
\text { greater }(\%)\end{array}$ & $\begin{array}{c}\text { Fruit } 7.6 \mathrm{~cm} \text { or } \\
\text { greater }(\%)\end{array}$ & $\begin{array}{l}\text { Total yield } \\
\left(\mathrm{kg} \cdot \mathrm{ha}^{-1}\right)^{\mathrm{y}}\end{array}$ & $\begin{array}{c}\text { Yield of } \\
\text { high market } \\
\text { value size } \\
\text { fruit }\left(\mathrm{kg} \cdot \mathrm{ha}^{-1}\right)^{\mathrm{x}}\end{array}$ \\
\hline & & & $\begin{array}{c}\text { Perpendicular V } \\
\text { John Boy } \\
2008\end{array}$ & & \\
\hline Fan pruning, $20 \% \mathrm{FB}^{\mathrm{w}}$ & $7.2 \mathrm{a}^{\mathrm{v}}$ & $99 \mathrm{a}$ & $60 \mathrm{a}$ & $18,240 \mathrm{c}$ & $13,594 \mathrm{~b}$ \\
\hline Partial pruning, $20 \% \mathrm{FB}$ & $7.2 \mathrm{a}$ & $96 \mathrm{ab}$ & $46 \mathrm{ab}$ & $22,175 \mathrm{bc}$ & $11,396 \mathrm{c}$ \\
\hline Standard pruning, $20 \% \mathrm{FB}$ & $7.2 \mathrm{a}$ & $96 \mathrm{ab}$ & $58 \mathrm{a}$ & $24,578 \mathrm{~b}$ & $15,495 \mathrm{a}$ \\
\hline Hand-thinned control, 35 & $7.0 \mathrm{~b}$ & $91 \mathrm{~b}$ & $33 \mathrm{~b}$ & $32,090 \mathrm{a}$ & $12,340 \mathrm{bc}$ \\
\hline
\end{tabular}

DAFB

Delayed pruning, $80 \% \mathrm{FB}^{\mathrm{u}}$

Detail pruning, $80 \%$ FB

Standard pruning, $80 \%$ FB

Hand-thinned control, 35

DAFB

$7.5 \mathrm{a}$
$7.1 \mathrm{~b}$
$6.9 \mathrm{~b}$

$7.5 \mathrm{a}$

$7.1 \mathrm{~b}$

$6.9 \mathrm{~b}$

Fan pruning, 20\% FB

Partial pruning, 20\% FB

Standard pruning, 20\% FB

Hand thinned control, 35 DAFB

$6.8 \mathrm{a}$
$6.9 \mathrm{a}$
$6.8 \mathrm{a}$
$6.6 \mathrm{~b}$

Fan pruning, $60 \% \mathrm{FB}$
Partial pruning, $60 \% \mathrm{FB}$
Standard pruning, $60 \% \mathrm{FB}$
Hand thinned control, 35
DAFB

$7.4 \mathrm{a}$

$7.7 \mathrm{a}$

$7.6 \mathrm{a}$

$6.9 \mathrm{~b}$

Detail pruning, $60 \% \mathrm{FB}$

Partial pruning, $60 \% \mathrm{FB}$

$8.1 \mathrm{a}$

$7.9 \mathrm{~b}$

Standard pruning, $60 \% \mathrm{FB}$

Hand thinned control, 35

DAFB

$7.9 \mathrm{~b}$

$7.7 \mathrm{~b}$

Detail pruning, $60 \% \mathrm{FB}$

Partial pruning, $60 \% \mathrm{FB}$

Standard pruning, $60 \%$ FB

Hand thinned control, 35

DAFB

${ }^{\mathrm{z}}$ Fruit diameter and packout distribution determined on 40 fruit harvested per treatment from each of six replicates. $1 \mathrm{~cm}=0.3937 \mathrm{inch}$.

${ }^{y}$ Yield calculated from fruit counts per scaffold and percent size distribution at harvest.

${ }^{x}$ Higher market value fruit are all fruit $7.62 \mathrm{~cm}$ or greater ( 3.0 inches) diameter for 'John Boy' and all fruit $6.985 \mathrm{~cm}$ or greater (2.75 inches) for 'While Lady', 'Loring', and PF20-007. $1 \mathrm{~kg} \cdot \mathrm{ha}^{-1}=0.8922 \mathrm{lb} / \mathrm{acre}$. ${ }^{\mathrm{w}} \mathrm{FB}=$ full bloom; DAFB = days after full bloom.

'Mean separation within columns, cultivars, and years by Fisher's protected least significant difference test at $P \leq 0.05$.

${ }^{u}$ No data, because trees were pruned too late for comparison.

Follow-up hand-thinning costs for the green fruit-thinned control treatments averaged \$419/ha in the perpendicular V trials and $\$ 219 /$ ha in the open-center trials (Table 4). The best treatments resulted in a thinning savings of $\$ 120 /$ ha to $\$ 282 /$ ha and $\$ 26 /$ ha to \$46/ha, respectively. Thinning savings calculations included reduced follow-up hand-thinning inputs and added mechanical thinner, tractor, and labor inputs.
Realized economic savings. The savings in hand-thinning time and increases in fruit size associated with the detail and partial pruning treatments increased the value of the peach crops beyond that of hand-thinning alone (Table 4). Net positive economic impact (realized economic savings beyond hand-thinning alone) ranged from $\$ 473 /$ ha to $\$ 2875 /$ ha in perpendicular V trials and $\$ 28 /$ ha to $\$ 293 /$ ha in open-center trials. The 
only treatment that resulted in a negative net economic impact was standard pruning in the 2009 'John Boy' study, and although followup hand-thinning time was reduced by this treatment, fruit size was unaffected.

We did not measure pruning time in these studies. Pruning labor ranks third and represents $\approx 21 \%$ of total labor in peach, behind harvest $(42 \%)$ and hand-thinning (28\%) (Krawczyk, 2010). Pruning modifications such as ours, which remove fruiting branches, could be expected to reduce fruit numbers by removing the bearing surface, thus reducing the labor required for thinning and harvest. Standard pruning in peach involves selecting desirable branches and thinning out undesirable branches and requires farm workers to make judgments about which branches to

remove. Partial and fan pruning methods both impose rules by which those branches growing in the specified orientations are removed without any requirement for judgment; thus, these methods could be expected to reduce pruning time somewhat. Detail pruning took somewhat longer than standard pruning because there were added steps; however, the detail cuts were based on branch size, requiring very little judgment.

Thinning efficacy with variable scaffold angles and accessibility rankings. Thinning efficacy was unaffected by the scaffold angle of perpendicular V-trained peach trees. Average scaffold angle was $65^{\circ}$ to $70^{\circ}$, the range was $55^{\circ}$ to $90^{\circ}$, and Pearson product moment correlations ranged from -0.24 to 0.16 (data not shown). Thinning efficacy, however, in-

Table 4. Follow-up hand-thinning cost, thinning savings, and net economic impact as affected by string thinner treatments applied to varying pruning modifications in 2008 and 2009.

\begin{tabular}{|c|c|c|c|}
\hline Thinning treatment & $\begin{array}{c}\text { Follow-up } \\
\text { hand-thinning cost } \\
(\$ / \mathrm{ha})^{\mathrm{z}}\end{array}$ & $\begin{array}{l}\text { Thinning } \\
\text { savings } \\
(\$ / h a)^{y}\end{array}$ & $\begin{array}{l}\text { Net economic } \\
\text { impact } \\
(\$ / h a)^{x}\end{array}$ \\
\hline & & $\begin{array}{c}\text { Perpendicular V } \\
\text { John Boy } 944 \text { trees/ha } \\
2008\end{array}$ & \\
\hline Fan pruning, $20 \% \mathrm{FB}^{\mathrm{w}}$ & 169 & 87 & 985 \\
\hline Partial pruning, $20 \% \mathrm{FB}$ & 131 & 126 & 597 \\
\hline Standard pruning, $20 \% \mathrm{FB}$ & 195 & 62 & 749 \\
\hline Hand-thinned control, 35 DAFB & 326 & - & - \\
\hline
\end{tabular}

Delayed pruning, $80 \% \mathrm{FB}^{\mathrm{v}}$

Detail pruning, $80 \% \mathrm{FB}$

Standard pruning, $80 \%$ FB

Hand-thinned control, 35 DAFB

326

John Boy 944 trees/ha 2009

$\begin{array}{rr}578 & 2009 \\ 368 & 71 \\ 581 & 282 \\ 685 & 69 \\ & -\end{array}$

White Lady 897 trees/ha 2008

\section{1}

124

185

310
Fan pruning, 20\% FB

Partial pruning, 20\% FB

Standard pruning, 20\% FB

Hand thinned control, 35 DAFB

83

120

59

2,875

2,336

2,445

White Lady 897 trees/ha 2009

322

322

322

Standard pruning, $60 \%$ FB

Hand thinned control, 35 DAFB

0
0
0
355

929

983
Detail pruning, 60\% FB

Partial pruning, 60\% FB

Standard pruning, $60 \% \mathrm{FB}$

Hand thinned control, 35 DAFB

210
217
243
269

creased for each 1-point increase in accessibility ranking based on regression analyses pooled across plots (Fig. 4). The Pearson product moment correlation for 'Allstar', which had moderate bloom density, was 0.80 , and the Pearson product moment correlation for 'Saturn', which had a heavy bloom density, was $0.50(P=0.05$; Fig. 5). The tractor operator could adjust the spindle angle to the scaffold angle and effectively thin a straight scaffold positioned perpendicular to the row, but not a crooked limb or one that was not perpendicular to the row. This finding indicates that extra attention should be given to laying out and training peach blocks that are to be mechanically thinned.

Implications for growers. Mechanical thinning, being a physical removal technique, has greater predictability than chemical thinning. Because the effects of physical removal are immediately visible, the level of crop removal can be determined by comparing preand post-thinning flower or fruit counts. A grower can therefore assess the level of crop removal and adjust the machinery to increase or reduce thinning as needed. However, the ability to ascertain the optimal cropload level

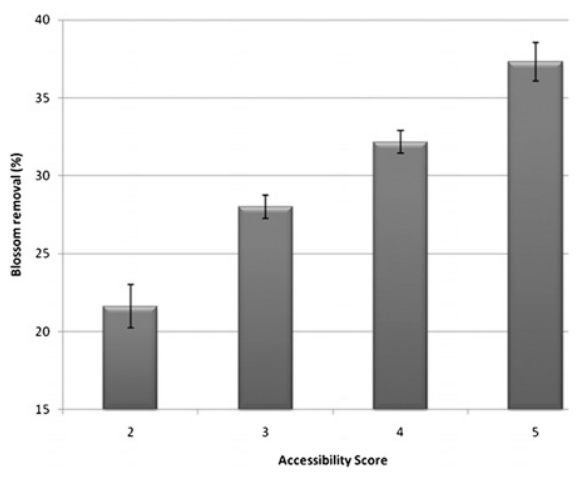

Fig. 4. Effect of scaffold accessibility $(1=$ poor to $5=$ excellent accessibility) on percent blossom removal across four perpendicular V-trained commercial-scale plots. Crooked scaffolds or scaffolds that were not perpendicular to the row were given the lower rankings, and straight scaffolds that were positioned close to $90^{\circ}$ from the row were given the highest accessibility ratings.

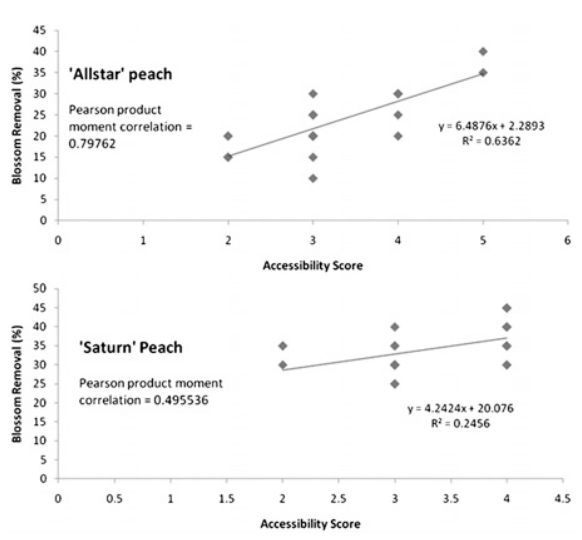

Fig. 5. Regression analyses comparing blossom removal for variable scaffold accessibility rankings for 'Allstar', which had moderate bloom density and 'Saturn', which had a heavy bloom density.
Detail pruning, $60 \% \mathrm{FB}$

Partial pruning, 60\% FB

Standard pruning, $60 \% \mathrm{FB}$

Hand thinned control, 35 DAFB
90

125

129

169

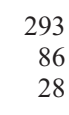

PF20-007 450 trees/ha 2009

46
11

7
181
zFollow-up hand-thinning cost is based on a labor rate of $\$ 8.50 / \mathrm{h}$ in 2008 and $\$ 8.75 / \mathrm{h}$ in 2009 . and labor input. Mechanical thinner cost is based on a 15 -years use
rate. Tractor cost is $\$ 12.00 / \mathrm{h}$; equipment operator cost is $\$ 12.00 / \mathrm{h}$.

${ }^{x}$ Net economic impact (realized economic savings) is defined as cost/benefit beyond hand-thinning alone and takes into account reduced hand-thinning inputs and increased value of fruit in higher size categories ${ }^{\mathrm{w}} \mathrm{FB}=$ full bloom; DAFB = days after full bloom.

${ }^{\mathrm{N}} \mathrm{No}$ data, because trees were pruned too late for comparison. 
and thus obtain the optimal balance of yield and fruit size distribution is still required. Because the potential negative economic consequence of overthinning a high-value crop such as stone fruit is great, it may be a safer strategy to use non-selective mechanical thinners to reduce but not entirely replace hand-thinning.

In the current trials, tree pruning and training modifications were shown to be factors that warrant special attention for obtaining the most consistent results from mechanical string thinning. Canopy accessibility by the string thinner can be improved by detail pruning to eliminate excessively long or short fruiting shoots, by pruning to remove shoots in less accessible regions of the canopy, and by tree training to maintain straight scaffolds. Given the current premiums for large fruit in the fresh fruit market, and the growing expense and potential shortage of farm labor, the application of mechanical thinners and adoption of narrow tree wall systems that enhance the benefits of this technology offer a near-term solution to these two critical components of fruit grower profitability.

\section{Literature Cited}

Baugher, T.A., K.C. Elliott, D.W. Leach, B.D. Horton, and S.S. Miller. 1991. Improved methods of mechanically thinning peaches at full bloom. J. Amer. Soc. Hort. Sci. 116:766-769.

Baugher, T.A., J. Schupp, K. Ellis, J. Remcheck, E. Winzeler, R. Duncan, S. Johnson, K. Lewis, G. Reighard, G. Henderson, M. Norton, A. Dhaddey, and P. Heinemann. 2010a. String blossom thinner designed for variable tree forms increases crop load management efficiency in trials in four United States peach-growing regions. HortTechnology 20:409-414.

Baugher, T.A., J. Schupp, K. Ellis, J. Remcheck, E. Winzeler, K. Lesser, and K. Reichard. 2010b. Mechanical string thinner reduces crop load at variable stages of bloom development of peach and nectarine trees. HortScience 45: $1327-1331$

Baugher, T.A., J. Schupp, K. Lesser, and K. Reichard. 2009. Horizontal string blossom thinner reduces labor input and increases fruit size in peach trees trained to open-center systems. HortTechnology 19:755-761.

Berlage, A.G. and R.D. Langmo. 1982. Machine vs. hand thinning of peaches. Trans. Amer. Soc. Agr. Eng. 25:538-543.

Bertschinger, L., W. Stadler, F.P. Weibel, and R. Schumacher. 1998. New methods for an environmentally safe regulation of flower and fruit set and of alternate bearing of the apple crop. Acta Hort. 466:65-70.

Byers, R.E. 1999. Effects of bloom-thinning chemicals on peach fruit set. J. Tree Fruit Production 2:59-78.

Byers, R.E. 1990. Thin peaches with water. Amer Fruit Grower 110:20-21.

Damerow, L. and M.M. Blanke. 2009. A novel device for precise and selective thinning in fruit crops to improve fruit quality. Acta Hort. 824: 275-280.

Damerow, L., A. Kunz, and M.M. Blanke. 2007. Regulation of fruit set by mechanical flower thinning. Erwerbs-Obstbau 49:1-9.

Diezma, B. and U.A. Rosa. 2005. Monitoring of fruit removal for mechanical thinning of peaches. Frutic 05:12-16.

Fallahi, E., B. Fallahi, J.R. McFerson, R.E. Byers, R.C. Ebel, R.T. Boozer, J. Pitts, and P.S Wilkins. 2006. Tergitol-TMN-6 surfactant is an effective blossom thinner for stone fruits. HortScience 41:1243-1248.

Glenn, D.M., D.L. Peterson, D. Giovannini, and M. Faust. 1994. Mechanical thinning of peaches is effective postbloom. HortScience 29:850-853.

Glozer, K. and J. Hasey. 2006. Mechanical thinning in cling peach. HortScience 41:995.

Harper, J.K., R.M. Crassweller, and D.E. Smith 2002. Impact of apple rootstock/cultivar on processing market profitability. J. Amer. Pomological Soc. 56:112-117.

Klein, J.D. and S. Cohen. 2000. Thinning nectarines and peaches at flowering with organosilicone surfactants. HortScience 35:385-519.
Krawczyk, G. (ed.). 2010. 2010-2011 Pennsylvania tree fruit production guide. Penn State College of Agr. Sci. Bul. AGRS-045.

Marini, R. 2009. Pruning to manage peach crop load. Penn State Fruit Times 28:1-4.

Miller, S., J. Schupp, T. Baugher, and S. Wolford. 2011. Performance of mechanical thinners for bloom or green fruit thinning in peaches. HortScience 46:43-51.

Miller, S. and T. Tworkoski. 2010. Blossom thinning in apple and peach with an essential oil. HortScience 45:1218-1225.

Osborne, J.L., T.L. Robinson, and R. Parra-Quezada. 2005. Chemical blossom thinning agents reduce crop load of 'Rising Star' peach in New York. Acta Hort. 727:423-428.

Powell, A.A., B.G. Hancock, E.E. Puls, Jr., S.G. Helmers, and M.H. Brown, Jr. 1975. Utilizing mechanical fruit thinning in commercial peach orchards. HortScience 10:142 (abstr.).

Rosa, U.A., K.G. Cheetancheri, C.J. Gliever, S.H. Lee, J. Thompson, and D.C. Slaughter. 2008. An electro-mechanical limb shaker for fruit thinning. Comput. Electron. Agr. 61:213221.

Schupp, J.R., T.A. Baugher, S.S. Miller, R.M. Harsh, and K.M. Lesser. 2008. Mechanical thinning of peach and apple trees reduces labor input and increases fruit size. HortTechnology 18:660-670

Stover, E.W. and D.W. Greene. 2005. Environmental effects on the performance of foliar applied plant growth regulators. HortTechnology 15:214-221.

U.S. Department of Agriculture. 2009. USDA agricultural marketing service report. USDA fruit and vegetable market news. 10 Dec. 2009 $<$ http://marketnews.usda.gov/portal/fv?paf_dm= full\&paf_gear_id $=1200002 \&$ startIndex $=1 \&$ $\mathrm{dr}=1 \&$ rowDisplayMax $=25 \&$ repType $=$ termPrice Daily $\& d r=1 \&$ loc Name $=\&$ commAbr $=\mathrm{PCH} \&$ commName $=$ PEACHES $>$.

Wilkins, B.S., R.C. Ebel, W.A. Dozier, J. Pitts, and R. Boozer. 2004. Tergitol TMN-6 for thinning peach blossoms. HortScience 39:1611 1613. 